\title{
Exploration of Early Childhood Literacy Ability based on Analytical Hierarchy Process (AHP)
}

\author{
Junita Dwi Wardhani ${ }^{1,2, *}$, M. Furqon Hidayatullah ${ }^{2}$, Asrowi $^{2}$, Wiranto $^{3}$, M. Nizam ${ }^{4}$, Eka Rahmawati $^{5}$ \\ ${ }^{1}$ Early Childhood Teacher Education Program, Universitas Muhammadiyah Surakarta, Indonesia \\ ${ }^{2}$ Doctoral Program of Education Science, Universitas Sebelas Maret, Indonesia \\ ${ }^{3}$ Faculty of Mathematics and Science, Universitas Sebelas Maret, Indonesia \\ ${ }^{4}$ Faculty of Engineering, Universitas Sebelas Maret, Indonesia \\ ${ }^{5}$ Primary Teacher Education Program, Universitas Muhammadiyah Surakarta, Indonesia
}

Received September 25, 2020; Revised November 20, 2020; Accepted November 29, 2020

\section{Cite This Paper in the following Citation Styles}

(a): [1] Junita Dwi Wardhani, M. Furqon Hidayatullah, Asrowi, Wiranto, M. Nizam, Eka Rahmawati , "Exploration of Early Childhood Literacy Ability based on Analytical Hierarchy Process (AHP)," Universal Journal of Educational Research, Vol. 8, No. 12A, pp. 7843-7852, 2020. DOI: 10.13189/ujer.2020.082573.

(b): Junita Dwi Wardhani, M. Furqon Hidayatullah, Asrowi, Wiranto, M. Nizam, Eka Rahmawati (2020). Exploration of Early Childhood Literacy Ability based on Analytical Hierarchy Process (AHP). Universal Journal of Educational Research, 8(12A), 7843-7852. DOI: 10.13189/ujer.2020.082573.

Copyright $\bigcirc 2020$ by authors, all rights reserved. Authors agree that this article remains permanently open access under the terms of the Creative Commons Attribution License 4.0 International License

\begin{abstract}
Strong early literacy skills will affect children's thinking skills in the future. The results of existing research indicate that learning in schools has not been able to make this happen. This research is a survey research to see the gap between children's literacy skills in the field and expected literacy abilities. So that it will be seen the components that can affect the literacy abilities of children aged 5-6 years. Currently, there are not many studies examining the influence of literacy components in developing children's literacy, because many researchers consider that all components are important. Therefore, a deeper study is needed to see the components that affect the development of children's literacy. The expected literacy ability is expert judgment which has been validated using the Analitycal Hierarchy Process (AHP). The data analysis technique used is descriptive analysis. The data collection techniques used were observation and questionnaires. The population in this study used simple random sampling. Respondents in this study were 150 children aged 5-6 years. The results showed that the children's ability to understand language components was $6.76 \%$, phonological awareness reached $5.73 \%$, basic reading skills $6.5 \%$, basic writing skills $7.8 \%$, and children's motivation in reading $3.37 \%$, so it can be concluded that based on the components of children's early literacy skills, the accumulated age of 5-6 years has only reached $30.16 \%$ of the expected. The contribution of
\end{abstract}

this research is to determine the appropriate literacy stimulation for children.

Keywords Early Literacy, Children Aged 5-6 Years, Analytical Hierarchy Process (AHP)

\section{Introduction}

One of the determinants of the success of children's learning is optimal early literacy skills; therefore the ability to read and write in the early grades has a very important role. Reading literacy is very important to encourage ongoing reading involvement in the future. Literacy is one of the most important areas of development [1]. Reading or literacy is a strategy to get and access all the information needed in life. Reading is the foundation for learning; therefore the literacy skills must be strong and sturdy.

Literacy promotion that starts early can help build a routine literacy activity that will last throughout a children's lifetime [2]. Literacy is a routine activity that cannot be separated from modern human life styles, even more in the world of education. Literacy is an interactive process that takes place between the reader and the text, so that the reader uses knowledge, skills, and strategies to 
determine what meaning is contained in the text [3].

The findings of [4] provide preliminary evidence to take advantage of class routines that normally occur, such as the Morning Greetings or Morning Meetings, in order to instill explicit teaching and writing opportunities for young children. The success of literacy is the foundation for children's education, health and welfare outcomes in the future. Thus, early identification of literacy needs is very important [5].

Early literacy experiences in early childhood are believed to form a strong foundation on the development of reading [6]. Interest and motivation in children's literacy activities are positively related to the achievement of their literacy. Early literacy skills are the knowledge, skills, and attitudes of early childhood that form the basis of reading and writing abilities [7]. Literacy experiences and activities will encourage children's literacy abilities [8]. Early childhood literacy development is a process of language development that begins at the time the child is born and continues to experience development during his lifetime.

The learning process is mediated by language; therefore literacy skill is always preceded by language development [9]. Literacy in early childhood is one component of aspects of child development, namely aspects of language development. Having strong alphabet knowledge early in life is a strong predictor of long-term reading and academic results [10].

Play activities in early childhood by utilizing Information and Communication Technology (ICT) are currently very effective, for example using an android, tablet or computer. Children are very fond and familiar with technology. Through the use of ICT, it will arouse motivation and answer children's high curiosity. Through the use of ICT, children learn a lot of knowledge which is sometimes impossible if taught in traditional ways. Based on [11] this environment and the people around children have a role in encouraging children to learn by introducing and showing objects, reading stories, accompanying children when children play with computers, talk while play, ask questions, and so forth. We can say adults become intermediaries for children to know the world around them [12].

Literacy activities should be done without coercion, without pressure, fun, and in accordance with the stages of child development. The introduction of literacy should be given in a framework for developing and optimizing all aspects of child development. Reading itself is actually a form of skill that can be trained [13]. Recommendations from the American Academy of Pediatrics and Reach Out and Read state that joint reading activities can be done from the birth of the children [2]. Interest in literacy activities, especially for children, is strongly influenced by their home literacy environment [14]. The home literacy environment is one of the important variables for developing reading comprehension [15].
In school, literacy learning is focused on 'printing literacy', reading, and writing [16]. The teacher plays an important role in developing and teaching literacy skills, such as the ability to read, write, and speak. Teachers need to carry out literacy strategies in their learning. Children learning ability is done through developing literacy skills in schools, for example using teaching materials or various media. Good and well-planned planning requires teachers who are expected to be able to develop children literacy skill. The teacher needs to create an attractive classroom environment for children to read and write and appreciate the use of children's language at home [17].

Learning at school is not yet able to realize this, as evidenced by the reading interest of children who are still very low [18]. In general, literacy teaching conducted by teachers has a relatively low quality [19]. The teacher has little time to plan or carry out new learning activities [20]. Teachers are relatively rarely involved in activities that actively support children's writing [21]. The research conducted by [22] motivated by the problem of the lack of consistent learning models about how to support the learning environment that can be beneficial for the development of children's literacy skills, so it is needed the effective training for teachers to facilitate and provide literacy experiences to children [23].

Children's opportunities to read make a positive contribution to their academic reading achievement; learn to read various shapes, colors, arrange puzzles, play guessing cards accompanied by the initial letters of one word according to the pictures on the card. The new ICT also brings new opportunities for children to develop literacy outside the classroom [24]. In recent ICT advancements, social robots have emerged as educational tools with the potential to improve language skills and early literacy in children. Social robots are defined as machines that can interact socially and communicate intelligently with humans. Literature review is conducted to explore current knowledge about social robots and language learning and early literacy in developing children in the age of 0 to 8 years [25]. The increasing use of smartphones and tablets sets the stage for new cellular-based education programs that seek to increase children's learning and involvement at school and at home. The phonological awareness component, word reading and early writing skills can be improved through the use of a smartphone [26].

International research results show that the literacy abilities of Indonesian students who represent Indonesian society in general are relatively low, especially in terms of language literacy [27]. Based on the data of Organisation for Economic Co-operation and Development [28], the level of literacy of Indonesian society based on the data of Programme for International Student Assessment [29] shows that Indonesia is ranked $64^{\text {th }}$ out of 65 countries that followed with a score of 396 from the OECD average score of 496. 
According to the PISA report, Indonesian education received a red report card (VOI, 4 December 2019) Indonesia's position was ranked $6^{\text {th }}$ from the bottom, or $74^{\text {th }}$ position out of 79 countries. The reduced level of literacy of Indonesian students is the cause of their critical thinking skills decline. Almost all Indonesian student competency scores declined from PISA 2015. Indonesian students' reading competency scores declined the most from 397 to 371 . The 2018 PISA survey places the quality of Indonesian education below Singapore, Thailand, Malaysia, and Brunei Darussalam for all areas of competency.

Seeing these various facts, a learning approach is needed where the teacher must be able to stimulate, guide, help, and direct their students to be able to develop their literacy abilities. Strengthening literacy is one way to implement the 2013 curriculum in learning. Literacy is a means for students to recognize, understand, and apply science. Literacy is an important ability that must be possessed by every student [18].

Early language skills for early childhood primarily emphasize the elements of listening, speaking, pre-reading, and pre-writing. All elements of early language skills in early childhood can be developed through the Whole Language Approach (WLA). WLA is a learning approach that is believed to be able to stimulate children's language abilities at school or in the classroom naturally. Education in developed countries has implemented WLA a lot in its learning, because it is believed that WLA is able to have a positive impact on children's language development. The WLA approach is currently a very trendy, popular, and important approach for early childhood education [30].

In the era of disruption or millennial era, the use of technology is something that cannot be avoided [31]. This indicates that the influence of information technology is very large and it cannot be denied that we need technology in education. Many studies discuss the importance of ICT in early childhood education [32], [33]. Using ICT shows that children can be very active and independent learners [34].

Research on literacy in early childhood has been widely carried out; therefore there are many components that can be used as a basis in developing literacy skills in children. In this study the ability to read and write was measured using an initial literacy skill measure developed by [9] which contains 5 early literacy components of early childhood, namely: 1) language skills, 2) phonological awareness, 3) basic reading skills, and 4) basic writing skills and 5) reading motivation. The five components of early literacy of children mentioned above are still very common and in certain circumstances, it is not yet seen which components can make a major contribution or influence in the development of children's early literacy [35]. Currently, there are not many studies examining the influence of literacy components in developing children's literacy. Many researchers consider that all components of literacy are important [35]. The studies above show that there is no study on the level of literacy components that can affect children's literacy development, so this study needs to be examined in depth. It is hoped that the gap between children's current literacy skills and those at the ability level needs to be further examined

In addition, to improve children's abilities, it is necessary to use a comprehensive method (WLA). This approach is used to improve children's literacy levels to be better in the future. Therefore, a deeper study is needed to see the components that affect the development of children's literacy. By knowing the influence of these components, it will become a foot hold in providing optimal literacy stimulation to children. Therefore, this study aims to see the gap between children's literacy skills in the field and the expected literacy skills so that the components that can affect the literacy skills of children aged 5-6 years will be seen.

\section{Methodology}

\subsection{Research Design}

This research is a survey research to see the gap between the literacy skills of children in the field and the expected literacy abilities so that the components that can affect the literacy abilities of children aged 5-6 years will be seen. The data analysis technique used is descriptive analysis. The data collection techniques used were observation and questionnaires. Observations were made by looking at the process of literacy learning activities during class. The questionnaire method uses a measuring instrument for early literacy skills developed by [9] which contains 5 components of early childhood literacy, namely: (1) language skills, (2) phonological awareness, (3) basic reading skills, and (4) basic skills writing and (5) reading motivation. Data analysis techniques were performed by data reduction, data presentation and data verification until drawing conclusions.

In this study, the initial questionnaire was distributed to experts to obtain valid information regarding the sequence of components that affect children's literacy skills. The experts involved in this research were $12.5 \%$ with the title of Professor, $62.5 \%$ of lecturers with Doctoral degrees with early literacy competencies for early childhood and $25 \%$ of practitioners who are competent in the field of early childhood education. The expected literacy ability is expert judgment which has been validated using the Analitycal Hierarchy Process (AHP). AHP is a hierarchical layered structure developed for decision making [36], [37]. Using a hierarchy of AHP criteria helps us to solve complex and complex problems. Interested parties (experts) provide an assessment and conclude all considerations for developing weights or priorities. So far, the use of AHP has not been widely used in research 
studies, although decision making using AHP is quite objective and rational. The evaluation results using the AHP method have been tested and proven to be more scientific, objective and take into account the elements of intuition and subjectivity [38], [39]. AHP steps can be seen in Figure 1:

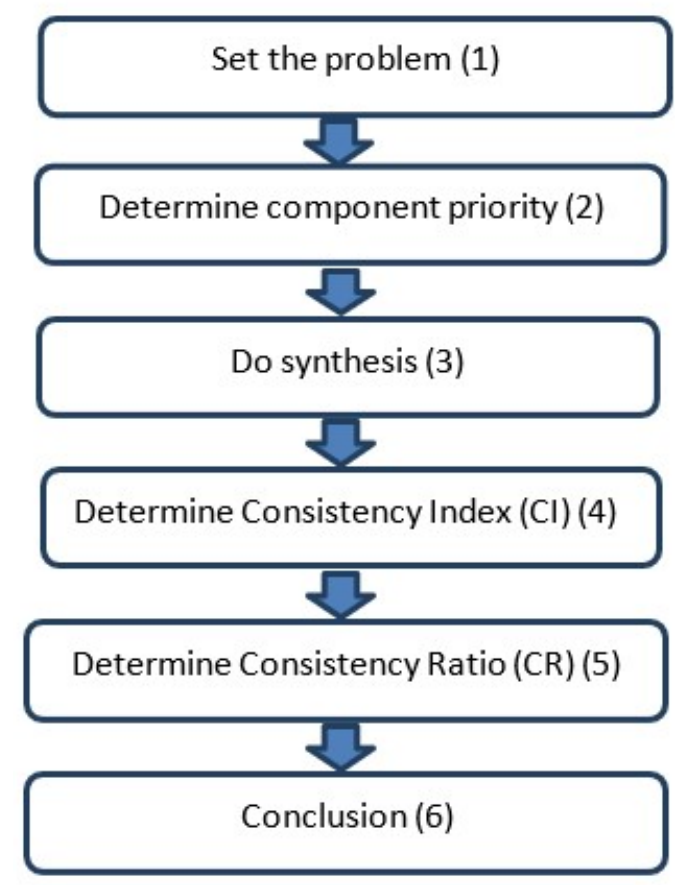

Figure 1. Stages in AHP

The stages in AHP are as follows:

1) Define the problem and determine the desired solutions

2) Create a hierarchical structure starting with a general goal, followed by criteria and choice alternatives.

3) Create a pairwise comparison matrix

4) Calculate the Consistency Index (CI) with the formula:

$$
\mathrm{CI}=\frac{\lambda \max -n}{(n-1)}
$$

5) Calculate the Consistency Ratio (CR) with the formula

$$
\mathrm{CR}=\frac{\mathrm{CI}}{\mathrm{RI}}
$$

If $\mathrm{CR}<0.1$ is consistent

If $\mathrm{CR} \geq 0.1$ is inconsistent, then the paired matrix on the criterion element must be repeated.

6) Conclusion

\section{The first step is to determine the problem}

The AHP approach is carried out by conducting a pair wise comparative analysis of each component. Based on the data above, it is necessary to look for the components that have the most important influence on children's literacy skills.

\section{The second step determines the priority of the} component

\section{- Intensity of Interest}

$1=$ The two components are equally important

$3=$ One component is slightly more important than the other components

$5=$ One component is more important than the other

7 = One component is absolutely more important than the other components

$9=$ One component is absolutely essential from the other components

2,4,6,8 $=$ Values between two adjacent balances

The third step: compiling a comparison matrix, namely:

The next step is to pool the opinions of several experts using the geometric mean equation:

$$
\mathrm{GM}=\sqrt[n]{(\mathrm{X} 1)(\mathrm{X} 2) \ldots \ldots(\mathrm{Xn})}
$$

Where:

$\mathrm{GM}=$ Geometric Mean X1 $=1$ st Expert

$\mathrm{X} 2=2 \mathrm{nd}$ Expert $\mathrm{Xn}=$ nth Expert

Table 1. Comparison Matrix

\begin{tabular}{|c|c|c|c|c|c|}
\hline Components & $\begin{array}{c}\text { Ability to } \\
\text { understand } \\
\text { language }\end{array}$ & $\begin{array}{c}\text { Phonological } \\
\text { awareness }\end{array}$ & Basic reading skill & Basic writing skill & $\begin{array}{c}\text { Reading } \\
\text { motivation }\end{array}$ \\
\hline Ability to understand language & 1 & 2.43 & 1.29 & 1.57 & 3 \\
\hline Phonological awareness & 0.412 & 1 & 2.326 & 1.71 & 3.14 \\
\hline Basic reading skill & 0.775 & 0.43 & 1 & 0.280 & 2.29 \\
\hline Basic writing skill & 0.637 & 0.584 & 3.57 & 1 & 3.57 \\
\hline Reading motivation & 0.333 & 0.318 & 0.437 & 0.280 & 1 \\
\hline Total & 3.157 & 4.763 & 8.622 & 4.840 & 13 \\
\hline
\end{tabular}


Table 2. Normalization

\begin{tabular}{|c|c|c|c|c|c|c|c|}
\hline \multirow[b]{2}{*}{ Components } & \multicolumn{5}{|c|}{ Eigen values/ Normalized } & \multirow[b]{2}{*}{ Total } & \multirow[b]{2}{*}{ Mean } \\
\hline & $\begin{array}{l}\text { Ability to } \\
\text { understand } \\
\text { language }\end{array}$ & $\begin{array}{l}\text { Phonological } \\
\text { awareness }\end{array}$ & $\begin{array}{c}\text { Basic reading } \\
\text { skill }\end{array}$ & Basic writing skill & $\begin{array}{l}\text { Reading } \\
\text { motivation }\end{array}$ & & \\
\hline $\begin{array}{l}\text { Ability to understand } \\
\text { language }\end{array}$ & 0.317 & 0.510 & 0.149 & 0.324 & 0.231 & 1.532 & 0.306 \\
\hline Phonological awareness & 0.130 & 0.209 & 0.269 & 0.353 & 0.242 & 1.205 & 0.241 \\
\hline Basic reading skill & 0.246 & 0.090 & 0.116 & 0.058 & 0.176 & 0.686 & 0.137 \\
\hline Basic writing skill & 0.202 & 0.123 & 0.414 & 0.207 & 0.275 & 1.219 & 0.243 \\
\hline Reading motivation & 0.106 & 0.067 & 0.051 & 0.058 & 0.077 & 0.358 & 0.072 \\
\hline \multicolumn{7}{|c|}{ Total } & 1 \\
\hline
\end{tabular}

The fourth step is to calculate the normalized Eigen factor by calculating the value of each row divided by the final number in the column

Column 1 row $1=1 / 3.157=0.317$

Column 1 row $2=0.142 / 3.157=0.130$

Column 1 row $3=0.775 / 3.157=0.246$

Column 1 row $4=0.637 / 3.157=0.202$

Column 1 row $5=0.333 / 3.157=0.106$ and so on, so the Eigen values/ Normalization table can be seen in table 2.

In the mean column, the number must be 1 otherwise the calculation is wrong and must be repeated. In the table above the calculation is 1 so the calculation is correct. Furthermore, it is necessary to calculate to find the Consistency Ratio (CR) to determine the consistency of existing data. To calculate the Consistency Ratio, we must first find the Consistency Index (CI).

The fourth step is to calculate the CI (Consistency Index).

$$
\begin{gathered}
\text { CI }=(\lambda \max -\mathrm{n}) /(\mathrm{n}-1) \\
\lambda \max =(3.157 \times 0.306)+(4,763 \times 0.241)+(8,622 \times \\
0.137)+(4,840 \times 0.243)+(13 \times 0.072)=5,409 \\
\text { CI }=(5.409-5) /(5-1)=0.102
\end{gathered}
$$

Consistency Ratio CR (CR)

$\begin{array}{ccccccccccc}\text { n } & 1 & 2 & 3 & 4 & 5 & 6 & 7 & 8 & 9 & 10 \\ \text { RI } & 0 & 0 & 5,8 & 0,9 & 1,12 & 1,24 & 1,32 & 1,41 & 1,45 & 1,49\end{array}$

Figure 2. Consistency Ratio (CR) Test

Where $\mathrm{n}=5$, the RI is at 1.12

\section{The fifth step is to calculate the CR (Consistency} Ratio).

If the CR is less than 0.1 , the result is consistent. If $\mathrm{CR}$ is greater than or equal to 0.1 , then the results are inconsistent and the paired matrix must be repeated to create. Consistency Ratio (CR) Test can be seen in Figure 2
Acceptable assessment results are those with $\mathrm{CR}<10 \%$ (0.1) Then: $\mathrm{CR}=\mathrm{CI} / \mathrm{IR}$

$$
=0.102 / 1.12=0.091
$$

$\mathrm{CR}=\mathbf{0 . 0 9 1}$ consistent (because it is less than 0.1 )

So based on the analysis above, the priority of children's literacy skills can be presented in the table as follows:

\section{The sixth step is Conclusion}

Table 3. Components of Child Literacy Ability based on Priorities

\begin{tabular}{|c|c|c|c|}
\hline No. & Components & Score & Rating \\
\hline 1. & Ability to understand language & 0.306 & Main priority \\
\hline 2. & Basic writing skill & 0.243 & Second priority \\
\hline 3. & Phonological awareness & 0.241 & Third priority \\
\hline 4. & Basic reading skill & 0.137 & Fourth priority \\
\hline 5. & Reading interest/ motivation & 0.072 & Fifth priority \\
\hline
\end{tabular}

\subsection{Research Subject}

The subjects in this study were 170 respondents. A total of 150 early childhood children participated in this study and 20 teachers/ principals were involved in this study. The research subjects were 150 early childhood students who attended 10 Kindergartens in the Solo Raya area. Of the 10 Kindergartens used in the study were class B groups (ages 5-6 years). This study only involved children in group B class because group B was a preparatory class for elementary school, so there were 10 class B groups involved in this study.

\subsection{Data Collection}

Data about the early literacy activities of children aged 5-6 years were collected by means of observation and questionnaires. Sources of data were also obtained in the form of oral data and written data. Observations were made by looking at the process of literacy learning activities during class. The questionnaire method uses a 
measuring instrument for early literacy skills developed by [9] which contains 5 components of early literacy in early childhood. Researchers conducted observations/ observations of 150 early childhood using instruments that have been prepared so that the child's early literacy skills can be seen. The questionnaire was given to 20 teachers/ principals for the sampling technique used by Simple Random Sampling, namely random sampling so that each child has the same opportunity to participate.

\subsection{Data Analysis}

This activity was carried out by spreading the initial literacy questionnaire that was developed by [9] to ten kindergartens in the Solo region. The results of the questionnaire were analyzed to produce data on the literacy abilities of children aged 5-6 years based on the conditions in the field. The data were compared with the expected data i.e. data from experts that have been validated using AHP. Comparison of the two children's literacy abilities data will show the existing gap.

\section{Results}

The results showed that children's ability to understand language was $6.76 \%$, children's phonological awareness reached $5.73 \%$, basic reading ability was $6.5 \%$, basic writing ability was $7.8 \%$, and children's motivation in reading was $3.37 \%$. Thus, it can be concluded that based on the component of children's early literacy skill, age of 5-6 years in the Solo region accumulated to only $30.16 \%$ of the expected. The results of the field study of children's early literacy skills can be seen in Figure 3 below:

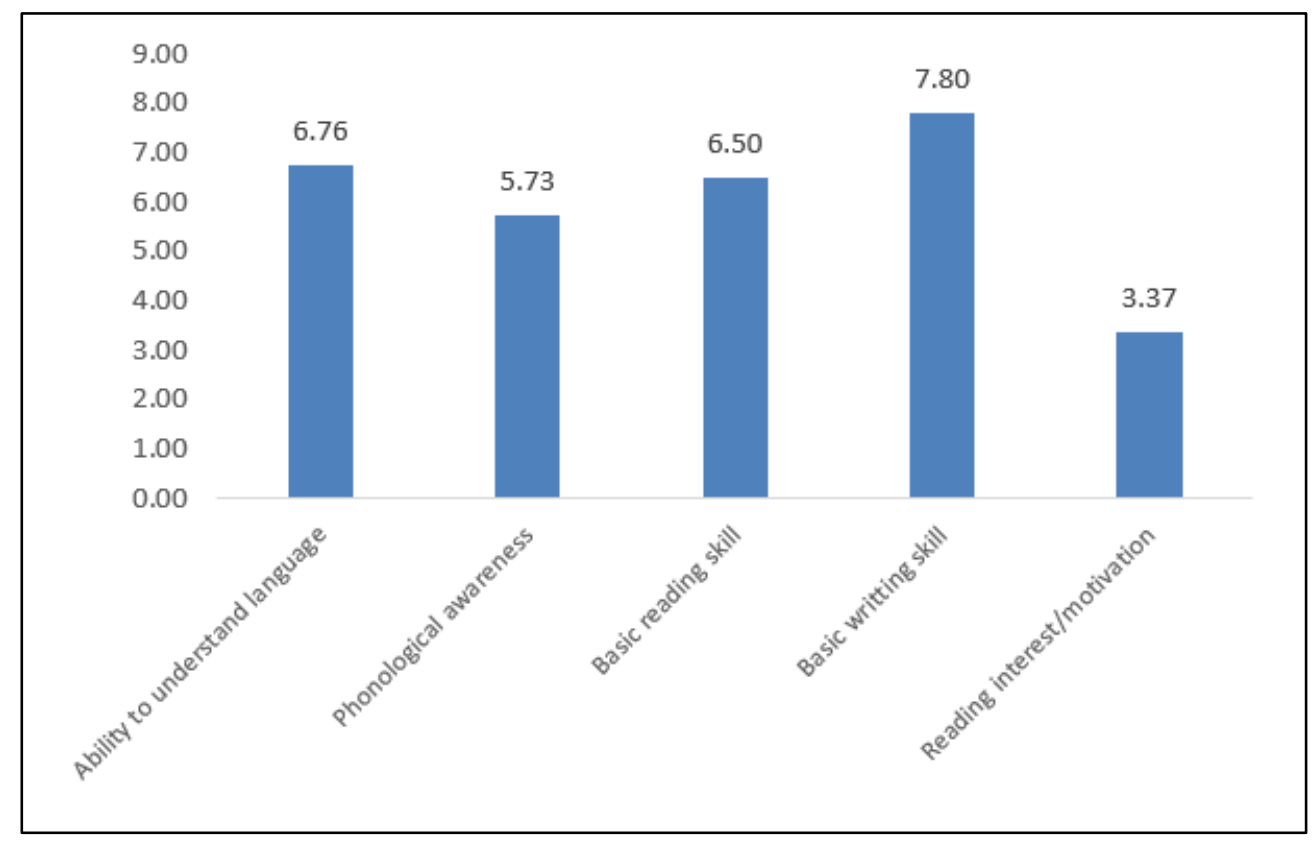

Figure 6. The components of early literacy skill of children in Solo region 
To find out the effect of each component, an appropriate calculation was needed. Assuming all components had the same value (had the same effect), the percentage obtained for each component was $20 \%$.

Table 4. The Early Literacy Skill of Children throughout Solo

\begin{tabular}{|c|c|}
\hline Literacy Components & Initial Score \\
\hline Ability to understand language & $20 \%$ \\
\hline Phonological awareness & $20 \%$ \\
\hline Basic reading skill & $20 \%$ \\
\hline Basic writing skill & $20 \%$ \\
\hline Reading interest/ motivation & $20 \%$ \\
\hline Total & $\mathbf{1 0 0} \%$ \\
\hline
\end{tabular}

The results of the component scores of children's early literacy skill can be seen in table 5

Table 5. The Score Table of Children Literacy Skill

\begin{tabular}{|c|c|c|}
\hline Literacy Components & Average & $\begin{array}{c}\text { Percentage based on } \\
\text { initial score (\%) }\end{array}$ \\
\hline Ability to understand language & 2.01 & 6.76 \\
\hline Phonological awareness & 1.86 & 5.73 \\
\hline Basic reading skill & 1.97 & 6.50 \\
\hline Basic writing skill & 2.18 & 7.80 \\
\hline Reading interest / motivation & 1.51 & 3.37 \\
\hline \multicolumn{2}{|c|}{ Total Score } & 30.16 \\
\hline
\end{tabular}

Based on the research conducted by [35] then the components that affect the ability of children's literacy based on expert judgment that has been validated using AHP results can be seen in table 6 .

Table 6. Children Literacy Skill based on Expert

\begin{tabular}{|c|c|c|c|}
\hline No & Components & Value & \% \\
\hline 1. & Ability to understand language & 0.306 & 30.60 \\
\hline 2. & Basic writing skill & 0.243 & 24.30 \\
\hline 3. & Phonological awareness & 0.241 & 24.10 \\
\hline 4. & Basic reading skill & 0.137 & 13.70 \\
\hline 5. & Reading interest / motivation & 0.073 & 7.30 \\
\hline
\end{tabular}

Table 7. The Score of Early Literacy Skill based on AHP

\begin{tabular}{|c|c|c|c|}
\hline No & Literacy Component & Average & $\begin{array}{c}\text { Percentage based } \\
\text { on AHP (\%) }\end{array}$ \\
\hline 1. & Ability to understand language & 2.01 & 10,30 \\
\hline 2. & Basic writing skill & 2.18 & 9,56 \\
\hline 3. & Phonological awareness & 1.86 & 6,91 \\
\hline 4. & Basic reading skill & 1.97 & 4,48 \\
\hline 5. & Reading interest / motivation & 1.51 & 1,24 \\
\hline
\end{tabular}

From table $6(30.60 \%)$, basic writing skills (24.30) and phonological awareness (24.10) were components that had a high percentage, thus those components influence children's literacy skills at the age of 5-6 years old.
Therefore, the component to understand language, basic writing skills, and phonological awareness will get greater literacy stimulation compared to the components of basic reading skill $(9.22 \%)$ and reading motivation $(6.06 \%)$. Then the percentage of initial component was calculated based on AHP, so table 5 was changed to table 7 .

After an expert score was obtained, it could be seen the gap between the initial literacy skill data in the field and the expected literacy skill conditions. The gap between the initial literacy skill data (in the field) and the expected literacy skill data can be seen in table 8 .

Table 8. The Gap on Children Literacy Skill Data (Field Study) with Expected Data

\begin{tabular}{|c|c|c|c|}
\hline Literacy Component & $\begin{array}{c}\text { Initial Score } \\
\text { After AHP(\%) }\end{array}$ & Gap (\%) & $\begin{array}{c}\text { Expert Score } \\
\text { (\%) }\end{array}$ \\
\hline $\begin{array}{c}\text { Ability to understand } \\
\text { language }\end{array}$ & 10.30 & 20.30 & 30.60 \\
\hline Basic writing skill & 9.56 & 14.74 & 24.30 \\
\hline Phonological awareness & 6.91 & 17.19 & 24.10 \\
\hline Basic reading skill & 4.48 & 9.22 & 13.70 \\
\hline $\begin{array}{c}\text { Reading interest / } \\
\text { motivation }\end{array}$ & 1.24 & 6.06 & 7.30 \\
\hline Total & 32.49 & 67.51 & 100 \\
\hline
\end{tabular}

From table 8, it can be seen the gap between children's literacy skill in the field and the expected data. The conclusion is that the children's literacy skill in the field has only reached $32.49 \%$ of $100 \%$. This means that there was a gap of $67.51 \%$. A large gap existed in the components of the ability to understand language (20.3\%), basic writing skills (14.74\%), and phonological awareness (17.19\%). This means that the three components have a great influence on children's literacy skill. It means that the components of understanding language, the basic ability of writing and phonological awareness were stimulated greater than the components of basic reading skill (9.22) and reading motivation (6.06).

\section{Discussion}

This study aims to look at the gap between the literacy abilities of children in the field and the expected conditions. Furthermore, it can be seen from the gap the components that can affect the literacy skill of children aged 5-6 years.

The results of the research showed that the children's ability to understand language was $6.76 \%$, the children's phonological awareness reached $5.73 \%$, basic reading ability was $6.5 \%$, basic writing skill was $7.8 \%$, and children's motivation in reading $3.37 \%$. Based on these results, it can be concluded that based on the criteria of the initial literacy skill of kindergarten B children throughout Solo Raya, the accumulation has only reached $30.16 \%$ of what was expected.

The gap between the preliminary study in the field and the expected data showed that the data on children's 
literacy skill in the field only reached $32.49 \%$ of the $100 \%$ expected (table 8). This meant that there was a gap of $67.51 \%$. A large gap existed in the components of understanding language $(20.3 \%)$, basic writing skills (14.74\%), and phonological awareness (17.19\%). This can be interpreted that the components of the ability to understand language, basic writing skills, and phonological awareness are influential components in the stimulation of children's literacy development. Since these three components shave a large influence on the stimulation of children, they will get greater stimulation compared to the components of basic reading skills $(9.22 \%)$ and reading motivation $(6.06 \%)$.

Language is a very important communication tool that is important for children, as children are able to express all their want and need through language. This is in accordance with the research [9] which states that children's learning processes are mediated by language, therefore literacy skill is always preceded by language development. Good phonological awareness will have a positive impact on children's literacy skill, whereas weak phonological awareness results in children experiencing reading disabilities. This is consistent with the statement [36] states that phonological awareness is the degree of children's sensitivity towards the sound structure in oral language.

The basic ability to read in early childhood is the ability to name letters and write them, spell simple words, recognize letters and signs around, identify books and titles, and carry out activities related to books. The earliest form of writing produced by early childhood is in the form of scribbles and drawings, so the teacher needs to stimulate activities related to the children's fine motor skills such as drawing, cutting, squeezing, and so forth. This opinion is in accordance with research [38], [40] that writing ability is facilitated by the teacher with fine motor activities using various materials in the class including markers, stamps, chalks, scissors, papers, pencils, pens, paints, crayons, blackboard chalks, drawing dictionaries, sticks, and others. Children's interest and motivation to read can be stimulated well with the support of reading environment. In addition to reading books, technology advancement is currently very possible for children to read through e-books. This is consistent with the statement [41], [42] that there are more and more young children who use tablets in their literacy experiences. The increasing use of smartphones and tablets sets the stage for new cellular-based education programs that seek to increase children's learning and involvement at school and at home. The phonological awareness component, word reading, and early childhood writing skills can be improved through the use of a smartphone [26].

\section{Conclusions}

The teacher plays an important role in developing children's stimulation. Stimulation must be fun, enjoyable, not make children feel burdened, able to form habits, interests, and positive motivation for children. In the era of disruption or millennial era, the use of ICT is something that cannot be avoided. This indicates that the influence of technology is huge and unavoidable.

The results of this study imply that teachers and principals must be adaptive in in the use of a variety of innovative learning approaches. The availability of ICT-based learning infrastructure is very helpful in facilitating children's learning based on their needs. Children are very adaptive in using ICT so that this will motivate children to learn. Play activities in early childhood by utilizing ICT media is very effective to use. The use of ICT is believed to increase children's competence. The use of the WLA integrated ICT model will be able to arouse motivation and answer children's high curiosity so that the children's early literacy skill will develop optimally.

Early literacy in early childhood is a very important component and is able to encourage on going reading involvement in the future. Literacy is a routine activity that cannot be separated from modern human life styles, even more in the world of education. This study only looks at the early literacy skill of children aged 5-6 years based on the existing components in schools, namely teachers and school principals. Exploration of parental involvement in stimulating children's literacy is an important part but has not been discussed in this study.

\section{REFERENCES}

[1] Theodotou E. Examining literacy development holistically using the play and learn through the arts (PLA) programme: A case study, Early Child Dev. Care, Vol. 189, No. 3, pp. 488-499, 2019. DOI: 10.1080/03004430.2017.1326914

[2] Sinclair E M Koepsell L McCleery E J and Zuckerman K. shared reading practices and early literacy promotion in the first year of life. J. Dev. Behav. Pediatr. Vol. 40, No. 7 pp. 538-546, 2019. DOI: 10.1097/ DBP.0000000000000690

[3] Ma'mur I. Membangun budaya literasi: meretas komunikasi global Banten: IAIN Suhada Press, 2010.

[4] Zhang C and E. Bingham G. Promoting high-leverage writing instruction through an early childhood classroom daily routine (WPI): A professional development model of early writing skills, Early Child. Res. Q. Vol. 49, No. 4, pp. 138-151, 2019. DOI: 10.1016/ j.ecresq.2019.06.

[5] Schluter P J et al., The Efficacy of preschool developmental indicators as a screen for early primary school - based literacy interventions, Soc. Res. Child Dev. Vol. 91, No. 1, pp. 59-76, 2020. DOI: 10.1111/cdev.13145.

[6] Levy B A Gong Z and Hessel S, 2005 Understanding print: Early reading development and the contribution of home literation of home literacy experiences, Exp. Child 
Psycology. Vol. 93, pp. 63-93, 2005.

[7] Whitehurst G Lonigan C Christopher B and Lonigan J, Feb. emergent literacy: development from pre-readers to readers, 2001 .

[8] Burgess S R Lonigan C J and Hecht S A. relations of the home literacy environment (HLE) to the development of reading-related abilities: A one-year longitudinal study, J. Pendidik. Dasar. Vol. 37, No. 4, pp. 408-426, 2002. DOI: 10.1598/RRQ.37.4.4

[9] Ruhaena L. Proses pencapaian kemampuan literasi dasar anak prasekolah dan dukungan faktor-faktor dalam keluarga J. Psikol. Vol. 44, No. 3, pp. 177-184, 2013.

[10] Heilmann J J Moyle M J and Rueden A M. No title topics early child. spec. educ. Vol. 38, No. 2, pp. 118-128, 2018. DOI: $10.1177 \% 2$ F0271121418 766636

[11] Vygotsky L S. Mind in Society: The development of higher psychological processes edition harvard university press, 1978.

[12] Elliott S N Kratochwill T R and Cook J L. Educational psychology: effective teaching, effective learning $3 \mathrm{rd}$ ed. mcgraw-hill humanities, 2000.

[13] Dobson L. Tamasya belajar: panduan merancang program bersekolah di rumah untuk anak usia dini Penerbit MLC, 2005 .

[14] Carroll J . A.J H F W and A.E B. Literacy interest, home literacy environment and emergent literacy skills in preschoolers, J. Res. Read. Vol. 42, No. 1, pp. 150-161, 2019.

[15] Guzmán-Simón F Gil-Flores Jand PachecoCosta A. Home literacy environment and reading comprehension in Spanish primary education, J Res. Read Vol. 43, No. 2, pp. 229-247, 2020. DOI:10.1111/ 1467-9817.12299.

[16] McKee L L and Heydon R M. Orchestrating literacies: print literacy learning opportunities within multimodal intergenerational ensembles J. Early Child. Lit. Vol.15, No. 2, pp. 227-255, 2015.

[17] Fokum L Yewande and Thomas J. Exploring how teachers teach literacy at grade one in Jamaica: a pilot study of three classrooms, Early Child Dev. Care. Vol.188, No. 9, pp. 1234-1245, 2018.

[18] Sari N A M Y Sujana I W and Ganing N N. Hubungan antara kemampuan literasi dengan kompetensi inti pengetahuan bahasa indonesia siswa kelas v SD gugus letkol wisnu denpasar utara tahun pelajaran 2017/2018 indones. J. Educ. Res. Rev.1, 2 pp. 94-103, 2018. DOI: $0.23887 /$ ijerr.v1i2.14708.

[19] Justice L Mashburn A Hamre B and Pianta R, Mar. Quality of language and literacy instruction in preschool classrooms serving at-risk pupils early child. res. Q. Vol. 23, No.1, pp. 51-68, 2008. DOI: 10.1016/ j.ecresq.2007.09.004.

[20] Powell D R. The Head Start program 6th ed.Merrill / Pearson, 2013.

[21] Gerde H K Bingham G E and Pendergast M L. Reliability and validity of the Writing Resources and Interactions in Teaching Environments (WRITE) for preschool classrooms
Early Child. Res. Q. Vol. 31, No. 2, pp. 34-46, 2015. DOI:10.1016/j.ecresq.2014.12.008.

[22] Hilman H Musthafa B and Agustin M. The design of literacy environment model in primary school J. Phys. Conf. Ser. Vol.1470, pp. 12013, 2020. DOI: $10.1088 / 1742-6596 / 1470 / 1 / 012013$

[23] Matsumoto H and Tsuneda M M. Teachers' beliefs about literacy practices for young children in early childhood education and care settings Int. J. Early Years Educ. Vol. 27, No. 4, pp. 441-456, 2019.

[24] Cummings $\mathrm{S}$ McLaughlin $\mathrm{T}$ and Brian F. Examining preadolescent children's engagement in out-of-school literacy and exploring opportunities for supporting literacy development. Aust. J. of Language Lit. Vol. 41, No. 2, pp. 103-116, 2018

[25] Neumann M M. Social robots and young children's early language and literacy learning Early Child. Educ. J. Vol. 48 pp. 157-170, 2020. DOI: 10.1007/s10643-019-00997-7.

[26] Amorim A Jeon L Abel Y Felisberto E Barbosa L and Dias $\mathrm{N}$, Mar. Using escribo play video games to improve phonological awareness, early reading, and writing in preschool. Educ. Res. Vol. 49, No. 3, pp. 188-197, 2020.

[27] Kharizmi M. Kesulitan siswa sekolah dasar dalam meningkatkan kemampuan literasi. J. Pendidik Dasar. Vol. 2, No. 2, pp. 11-21, 2015.

[28] OECD. Result in Focus Program for International Student, 2014.

[29] PISA, Result in Focus Program for International Student, 2012.

[30] Huang L-Y. Learning to read with the whole language approach: the teacher's view English Lang. Teach. Vol. 7, No 5, pp. 71-77, 2014. DOI: 10.5539/elt.v7n5p71.

[31] Hidayatullah F. 11 Kebijakan UNS unggul 2019-2023. dipresentasikan pada seminar pemilihan Rektor Universitas Sebelas Maret Surakarta, 2019.

[32] Marsh J. Young children's play in online virtual worlds J. Early Child. Res. Vol. 8, No. 1, pp. 23-39, 2010. DOI: 10.1177/1476718X09345406.

[33] Wohlwend K. Early adopters: Playing new literacies and pretending new technologies in print-centric classrooms J. Early Child. Lit. Vol. 9, No. 2, pp. 119-143, 2009. DOI: $10.1177 / 1468798409105583$

[34] Watts D M and Lioyd C. The use of innovative ICT in the active pursuit of literacy J. Comput. Assist. Learn. Vol. 20, pp. 50-58, 2004. DOI: 10.1111/j.1365-2729. 2004.00065.x.

[35] Wardhani J D Hidayatullah M F Asrowi Wiranto and Nizam, Analysis of priority literacy determination in early childhood through analytical hierarchy (AHP) Int. Sci. Technol. Res. Vol. 9 No. 4, pp. 801-807, 2020

[36] Anthony J L and Francis D J. Development of Phonological Awareness Curr. Dir. Psychol. Sci. Vol. 14, No. 5, pp. 255 259, 2005. DOI: 10.1111/ j.0963-7214.2005.00376.x.

[37] Saaty T L. Decision-making with the AHP: Why is the principal eigen vector necessary Eur. J. Oper. Res.145 pp. 85-91, 2003. 
[38] Morrow L M. Developing Literacy in Preschool New York: Guilford Press, 2007.

[39] Yin Q. An Analytical Hierarchy Process Model For The Evaluation Of College Experimental Teaching Quality J. Technol. Sci. Educ. Vol. 3, No. 2, pp. 59, 2013.

[40] Otto B. Literacy development in early childhood : reflective teaching for birth to age eight / Beverly Otto Upper Saddle
River, N.J. : Pearson/Merrill Prentice Hall, 2008.

[41] Korat $\mathrm{O}$ and Falk Y. Ten years after: Revisiting the question of e-book quality as early language and literacy support J. Early Child. Lit. Vol. 19, pp. 206-223, 2019. DOI: $10.1177 / 1468798417712105$.

[42] Rideout V. The Common sense census: Media use by kids age zero to eight, 2017. 